\title{
Complete genome sequence of Streptococcus agalactiae strain GBS85147 serotype of type la isolated from human oropharynx
}

\author{
Edgar Lacerda de Aguiar ${ }^{1}$ Diego César Batista Mariano ${ }^{1}$, Marcus Vinícius Canário Viana', \\ Leandro de Jesus Benevides', Flávia de Souza Rocha', Letícia de Castro Oliveira', Felipe Luiz Pereira², \\ Fernanda Alves Dorella ${ }^{2}$, Carlos Augusto Gomes Leal ${ }^{2}$, Alex Fiorini de Carvalho², Gabriela Silva Santos ${ }^{3}$, \\ Ana Luiza Mattos-Guaraldi ${ }^{4}$, Prescilla Emy Nagao ${ }^{3}$, Siomar de Castro Soares ${ }^{5}$, Syed Shah Hassan ${ }^{1}$, \\ Anne Cybele Pinto ${ }^{1}$, Henrique César Pereira Figueiredo ${ }^{2}$ and Vasco Azevedo ${ }^{1^{*}}$
}

\begin{abstract}
Streptococcus agalactiae, also referred to as Group B Streptococcus, is a frequent resident of the rectovaginal tract in humans, and a major cause of neonatal infection. The pathogen can also infect adults with underlying disease, particularly the elderly and immunocompromised ones. In addition, S. agalactiae is a known fish pathogen, which compromises food safety and represents a zoonotic hazard. This study provides valuable structural, functional and evolutionary genomic information of a human S. agalactiae serotype la (ST-103) GBS85147 strain isolated from the oropharynx of an adult patient from Rio de Janeiro, thereby representing the first human isolate in Brazil. We used the lon Torrent PGM platform with the 200 bp fragment library sequencing kit. The sequencing generated $578,082,183 \mathrm{bp}$, distributed among 2,973,022 reads, resulting in an approximately 246-fold mean coverage depth and was assembled using the Mira Assembler v3.9.18. The S. agalactiae strain GBS85147 comprises of a circular chromosome with a final genome length of 1,996,151 bp containing 1,915 protein-coding genes, 18 rRNA, 63 tRNA, 2 pseudogenes and a $\mathrm{G}+\mathrm{C}$ content of $35.48 \%$.
\end{abstract}

Keywords: Streptococcus agalactiae, Human pathogenic bacteria, Oropharynx, Complete genome sequence, lon torrent Abbreviations: CPS, Capsular polysaccharides; GBS, Group B Streptococcus; NT, Not type; PGM, Personal genome machine.

\section{Introduction}

Streptococcus agalactiae is a bacterial pathogen, distributed worldwide, that causes diseases in humans and animals [1]. In humans, it is frequently associated with meningitis, neonatal sepsis and may also affect immunocompromised adults and the elderly [2]. S. agalactiae is responsible for the most fatal bacterial infections in human newborns [3]. In fish, the pathogen causes meningoencephalitis and septicemia worldwide, in both freshwater and salt-water species $[4,5]$. Consumption of fish

\footnotetext{
* Correspondence: vasco@icb.ufmg.br

'Laboratory of Cellular and Molecular Genetics (LGCM), Federal University of Minas Gerais, Belo Horizonte, Brazil

Full list of author information is available at the end of the article
}

has been associated with an increased risk of colonization by $S$. agalactiae serotypes Ia and Ib in people [6]. S. agalactiae continues to be a major cause of subclinical mastitis in dairy cattle, which is the dominant health disorder affecting milk production in the dairy industry, and is responsible for substantial financial losses in that industry worldwide [7].

S. agalactiae is of great medical and veterinary importance due to a high social and economic impact [8], together with the incidence of diesase in different hosts [9]. The incidence of invasive infections unrelated to pregnancy in human adults and animals is increasing worldwide [10]. Therefore, further studies in the area remains necessary. Since the 1990s, serotype V emerged 


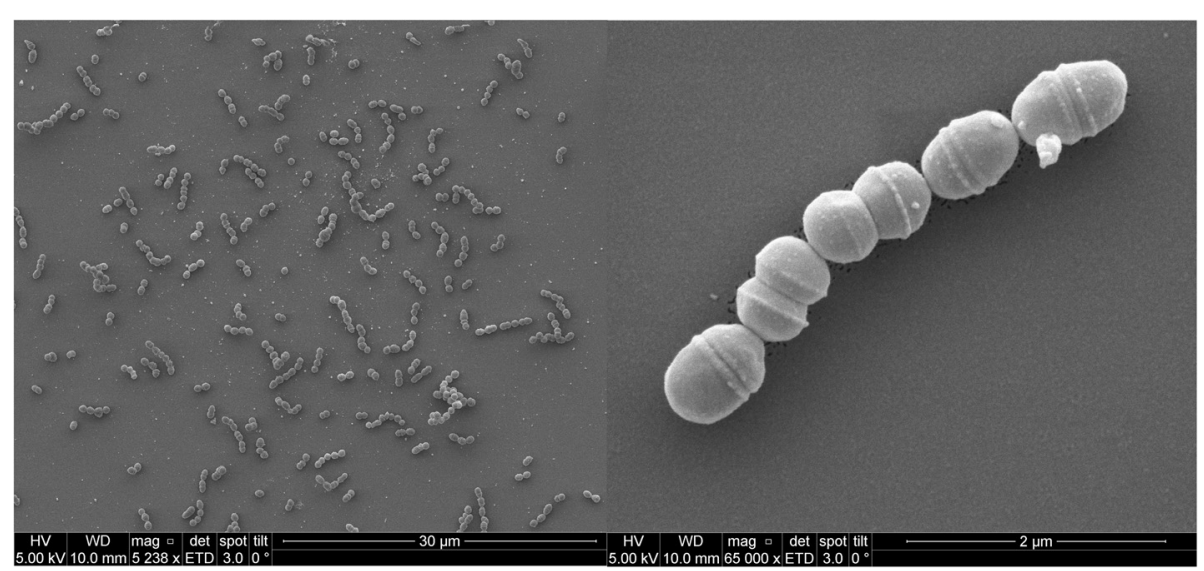

Fig. 1 SEM photomicrograph of S. agalactiae Gbs85147. Scanning electron microscopy of Streptococcus agalactiae strain GBS85147 grown in liquid media after $8 \mathrm{~h}$. Scale bars, 2 and $30 \mu \mathrm{m}$, respectively

in the United States as the most frequent S. agalactiae serotype causing invasive disease in nonpregnant adults [11]. Nowadays, other serotypes including Ia and III have also been recognized in different countries as significant cause of invasive diseases [12]. Comparative genomic studies among several S. agalactiae strains of the different serotypes will contribute to a better understanding of the biological complexity of the species. One such reason drove this study for genome sequencing, assembly and annotation of the GBS85147 S. agalactiae serotype Ia and Sequence Type 103 (ST-103) strain. The pathogenic potential of this human isolate obtained from the oropharynx of an asymptomatic female patient suffering of various recurrent pharyngitis episodes has been increasingly observed in different investigations [13-16]. From six S. agalactiae strains of Ia, III and V serotypes, only serotype Ia, including strain GBS85147, was capable of triggering a respiratory oxidative burst during adherence to the surface of activated macrophages. This activity was demonstrated by NADPH-oxidase activation within phagocytic vacuoles, indicating a high ability of strain GBS85147 isolated from an asymptomatic patient to survive in aerobic stress conditions. Moreover,

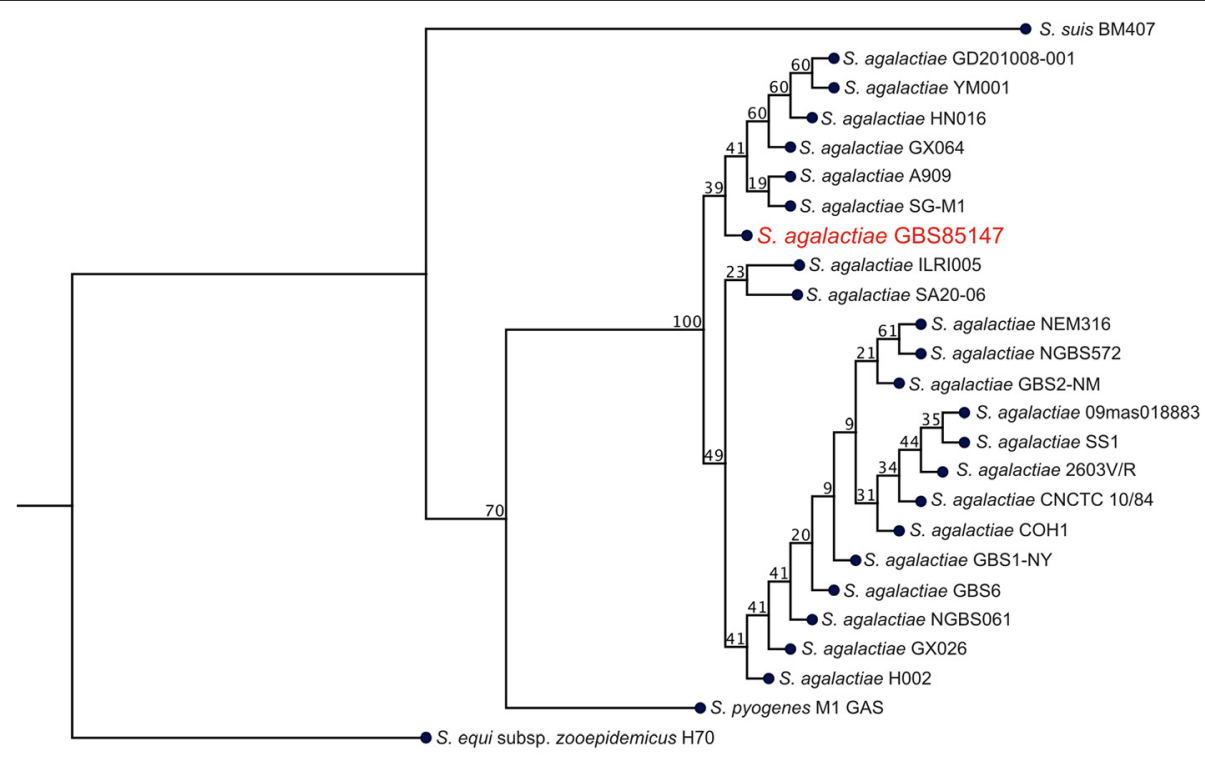

Note: Branches shorter than 0,0007 are shown as having length 0,0007

Fig. 2 Phylogenetic tree of S. agalactiae GBS85147 strain representing its position relative to other type strains. The phylogenetic tree was generated using S. agalactiae GBS85147 strain, 21 strains of Streptococcus agalactiae, and 3 strains from the genus Streptococcus as outgroup strains available at GenBank. The align and tree were constructed with CLC Genomic Workbench using Neighbor Joining method and Jukes-Cantor measure of nucleotide distance with 1000 bootstrap replications 
Table 1 Classification and general features of S. agalactiae strain GBS85147 - MIGS [27]

\begin{tabular}{|c|c|c|c|}
\hline MIGS ID & Property & Term & Evidence code $^{a}$ \\
\hline & Classification & Domain Bacteria & TAS [47] \\
\hline & & Phylum Firmicutes & TAS [48] \\
\hline & & Class Bacilli & TAS [49] \\
\hline & & Order Lactobacillales & TAS [50] \\
\hline & & $\begin{array}{l}\text { Family } \\
\text { Streptococcaceae }\end{array}$ & TAS [51] \\
\hline & & Genus Streptococcus & TAS [52] \\
\hline & & $\begin{array}{l}\text { Species Streptococcus } \\
\text { agalactiae }\end{array}$ & TAS [53] [54] \\
\hline & & Strain GBS85147 & IDA \\
\hline & & Sorotype la & IDA \\
\hline & Gram stain & Positive & IDA [10] \\
\hline & Cell shape & Coccus-shaped & IDA [18] \\
\hline & Motility & Non-motile & IDA [10] \\
\hline & Sporulation & Non-sporulating & IDA [10] \\
\hline & $\begin{array}{l}\text { Temperature } \\
\text { range }\end{array}$ & Mesophile & TAS [54] \\
\hline & $\begin{array}{l}\text { Optimum } \\
\text { temperature }\end{array}$ & $37^{\circ} \mathrm{C}$ & IDA \\
\hline & $\begin{array}{l}\text { pH range; } \\
\text { Optimum }\end{array}$ & $5.4-9.4 ; 7.4$ & IDA \\
\hline & Carbon source & Not Reported & NAS [19] \\
\hline MIGS-6 & Habitat & Human pharynx & IDA [8] \\
\hline MIGS-6.3 & Salinity & 4.0 to $6.0 \%$ & IDA [54] \\
\hline MIGS-22 & $\begin{array}{l}\text { Oxygen } \\
\text { requirement }\end{array}$ & Facultative anaerobe & IDA [18] \\
\hline MIGS-15 & Biotic relationship & Symbiotic & IDA [8] \\
\hline MIGS-14 & Pathogenicity & Pathogen & IDA [13] \\
\hline MIGS-4 & $\begin{array}{l}\text { Geographic } \\
\text { location }\end{array}$ & Rio de Janeiro, Brazil & \\
\hline MIGS-5 & $\begin{array}{l}\text { Sample collection } \\
\text { time }\end{array}$ & Not reported & IDA \\
\hline MIGS-4.1 & Latitude & Not reported & IDA \\
\hline MIGS-4.2 & Longitude & Not reported & IDA \\
\hline MIGS-4.4 & Altitude & Not reported & IDA \\
\hline
\end{tabular}

${ }^{a}$ Evidence codes - IDA inferred from direct assay, TAS traceable author statement (i.e., a direct report exists in the literature), NAS non-traceable author statement (i.e., not directly observed for the living, isolated sample, but based on either a generally accepted property for the species or anecdotal evidence). These evidence codes are from the Gene Ontology project [55]

the invasive potential of strain GBS85147 was also demonstrated by bacterial adherence, invasion and survival $(24 \mathrm{~h})$ in the intracytoplamatic environment of endothelial cells. Moreover, the detection of sialic acid in bacteria is limited to a few examples, which, strikingly, are all pathogenic, including $S$. agalactiae. Similar to serotypes III and $\mathrm{V}$, sialic acid residues were also detected on the surface of serotype Ia GBS85147 strain. These findings reinforce the
Table 2 Project information

\begin{tabular}{lll}
\hline MIGS ID & Property & Term \\
\hline MIGS-31 & Finishing quality & Finished \\
MIGS-28 & Libraries used & Fragment \\
MIGS-29 & Sequencing platforms & lon Torrent ${ }^{\text {TM }}$ PGM System \\
MIGS-31.2 & Fold coverage & 246x \\
MIGS-30 & Assemblers & Mira v3.9.18 \\
MIGS-32 & Gene calling method & FgenesB \\
& Locus tag & GBS85147 \\
& Genbank ID & CP010319 \\
& Genbank Date of Release & 05/01/2015 \\
& GOLD ID & \\
& BIOPROJECT & PRJNA263907 \\
& Source Material Identifier & SAMN03108598 \\
MIGS 13 & Project relevance & Medical, Veterinary, \\
& & Biotechnological \\
\hline
\end{tabular}

pathogenic potential of S. agalactiae GBS85147 strain by its ability to interfere specifically with opsonic components due to inhibition of the alternative complement pathway by serum deficient in a specific antibody $[16,17]$.

\section{Organism information Classification and features}

S. agalactiae is a Gram stain-positive, non-sporulating bacterium having a spherical shape with dimensions ranging from 0.2 to 1.0 microns [10] in diameter. On solid medium, $S$. agalactiae may form short chains or may form groups of double cocci. In liquid cells, the microorganism can form long chains (Fig. 1). The bacterium is a facultative anaerobe, catalase and oxidase negative, and is capable of lactic acid fermentation [18]. Lancefield identified the group $\mathrm{B}$ antigen, a peptidoglycan-anchored antigen (rhamnose, galactose, $\mathrm{N}$-acetylglucosamine, and glucitol), that defines the $S$. agalactiae species $[19,20]$.

A capsular polysaccharide antigen is used to classify $S$. agalactiae strains into serotypes [21]. The structure of the CPS is determined by genes encoding the enzymes responsible for its synthesis [22]. Serotype classification is based on the capsular antigen differences detected by PCR or by immunodiffusion techniques [23]. Currently, ten serotypes have been described (Ia, Ib, II, III, IV, V, VI, VII, VIII, IX); serotype IX was identified in 2007 [24]. In some strains, serotype identification is not possible due to the absence of the polysaccharide, caused by a mutation in the capsular genes [25]. The high degree of variation in the capsular structure is related to the virulence of different strains of S. agalactiae [26]. Those variations in the capsular structure may also explain its infection of unusual hosts such as camels, dogs, horses, seals, chickens, dolphins, cats, hamsters, frogs, and monkeys [9]. 


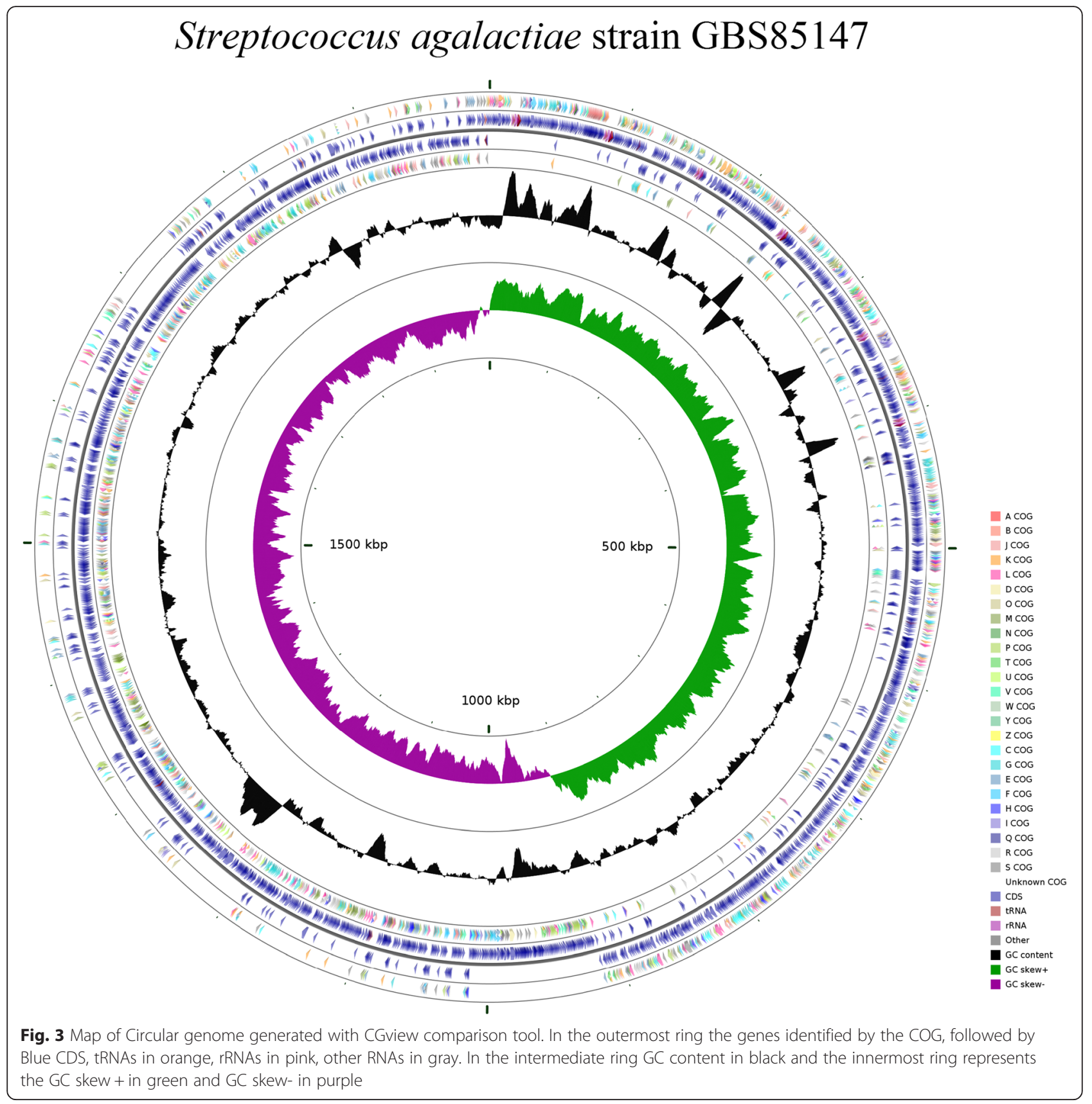

A phylogenetic analysis was performed using, in total 25 different strains, including S. agalactiae GBS85147 strain, plus 21 strains of Streptococcus agalactiae, and 3 strains from the genus Streptococcus, as outgroup strains, available at GenBank. The 16S rRNA genes, with mean length of $1,526 \pm 50 \mathrm{bp}$, were aligned with CLC Genomics Workbench (Qiagen, USA). The phylogenetic tree was generated in the same software with the Neighbor Joining method and Jukes-Cantor measure of nucleotide distance with 1,000 bootstrap replications. The phylogenetic tree demonstrates the placement of GBS85147 strain with other closely related strains from the same species, forming a specific clade in $100 \%$ of replications, while it remained distant from the Streptococcus spp. equi, suis, and pyogenes (Fig. 2). All 16S rRNA genes found on assembled contigs were in an equal form. Through this data we observed no contamination and evidence of correct identification of GBS85147 strain. Other features of the strain can be viewed in Table 1 .

\section{Genome sequencing information Genome project history}

S. agalactiae strain GBS85147, taken from a human oropharynx, was isolated in the Laboratory of Molecular 
Table 3 Genome statistics

\begin{tabular}{llc}
\hline Attribute & Value & \% of Total \\
\hline Genome size (bp) & $1,996,151$ & 100.00 \\
DNA coding (bp) & $1,804,165$ & 90.38 \\
DNA G + C (bp) & 708,380 & 35.48 \\
DNA scaffolds & 1 & 100.00 \\
Total genes & 1,998 & 100.00 \\
Protein coding genes & 1,915 & 95.84 \\
RNA genes & 81 & 4.05 \\
Pseudogenes & 2 & 0.1 \\
Genes in internal clusters & 26 & 1.30 \\
Genes with function prediction & 1,713 & 85.73 \\
Genes assigned to COGs & 1,564 & 78.27 \\
Genes with Pfam domains & 1,651 & 82.63 \\
Genes with signal peptides & 111 & 5.55 \\
Genes with transmembrane helices & 511 & 25.57 \\
CRISPR repeats & 1 & \\
\hline
\end{tabular}

Biology and Physiology of Streptococci in the city of Rio de Janeiro, RJ, Brazil. The genome was sequenced, assembled and annotated at the Laboratory of Cellular and Molecular Genetics in collaboration with the National Reference Laboratory for Aquatic Animal Diseases, Ministry of Fisheries and Aquaculture, both located at the Federal University of Minas Gerais, Belo Horizonte, Minas Gerais, Brazil. The genome project was deposited to the public database and the complete genome sequence is available in the GenBank under the accession number Genbank ID CP010319. Further, project information and association with MIGS version 2.0 compliance [27], are summarized in Table 2.

\section{Growth conditions and genomic DNA preparation}

S. agalactiae GBS85147 was obtained from the Streptococcus bacterial collection of the Laboratory of Molecular Biology and Physiology of Streptococci. The sample was grown on $30 \mathrm{~mL}$ of brain-heart-infusion broth (BHIHiMedia Laboratories Pvt. Ltda, India), with shaking for $48 \mathrm{~h}$ at $37{ }^{\circ} \mathrm{C}$. Chromosomal DNA was extracted from $30 \mathrm{ml}$ of bacterial culture. Briefly, the culture was centrifuged at $4{ }^{\circ} \mathrm{C}, 4000 \mathrm{rpm}$, for $15 \mathrm{~min}$. Cell pellets were resuspended in $600 \mu \mathrm{L}$ Tris/EDTA/NaCl $[10 \mathrm{mMTris} / \mathrm{HCl}$ (pH7.0), $10 \mathrm{mM}$ EDTA (pH8.0), and $300 \mathrm{mMNaCl}$, placed 2 times in tubes containing lysed cells with Precellys $^{\oplus}$ at rotations of $6500 \mathrm{rpm}$ for $30 \mathrm{~s}$. The DNA was purified using phenol/chloroform/isoamyl alcohol (25:24:1), precipitated using ethanol/ $\mathrm{NaCl} /$ glycogen ( $2.5 \mathrm{vol}$ ethanol, $10 \% \mathrm{NaCl}$ and $1 \%$ glycogen) and re-suspended in $30 \mu \mathrm{L}$ MilliQ ${ }^{\circledR}$. Finally, the DNA was stained using ethidium bromide and visualized in $1 \%$ agarose gel [28].
Table 4 Number of genes associated with general COG functional categories

\begin{tabular}{|c|c|c|c|}
\hline Code & Value & $\%$ age & Description \\
\hline J & 144 & 6.63 & Translation, ribosomal structure and biogenesis \\
\hline A & 0 & 0.00 & RNA processing and modification \\
\hline K & 115 & 5.29 & Transcription \\
\hline L & 97 & 4.46 & Replication, recombination and repair \\
\hline B & 1 & 0.05 & Chromatin structure and dynamics \\
\hline D & 20 & 0.92 & $\begin{array}{l}\text { Cell cycle control, Cell division, } \\
\text { chromosome partitioning }\end{array}$ \\
\hline V & 36 & 1.66 & Defense mechanisms \\
\hline $\mathrm{T}$ & 61 & 2.81 & Signal transduction mechanisms \\
\hline M & 106 & 4.88 & Cell wall/membrane biogenesis \\
\hline N & 7 & 0.32 & Cell motility \\
\hline U & 30 & 1.38 & Intracellular trafficking and secretion \\
\hline O & 58 & 2.67 & $\begin{array}{l}\text { Posttranslational modification, protein } \\
\text { turnover, chaperones }\end{array}$ \\
\hline C & 52 & 2.39 & Energy production and conversion \\
\hline G & 173 & 7.96 & Carbohydrate transport and metabolism \\
\hline $\mathrm{E}$ & 155 & 7.13 & Amino acid transport and metabolism \\
\hline $\mathrm{F}$ & 74 & 3.41 & Nucleotide transport and metabolism \\
\hline $\mathrm{H}$ & 50 & 2.30 & Coenzyme transport and metabolism \\
\hline I & 49 & 2.25 & Lipid transport and metabolism \\
\hline$P$ & 102 & 4.69 & Inorganic ion transport and metabolism \\
\hline Q & 23 & 1.06 & $\begin{array}{l}\text { Secondary metabolites biosynthesis, } \\
\text { transport and catabolism }\end{array}$ \\
\hline $\mathrm{R}$ & 219 & 10.08 & General function prediction only \\
\hline$S$ & 167 & 7.69 & Function unknown \\
\hline- & 434 & 19.97 & Not in COGs \\
\hline
\end{tabular}

The total is based on the total number of protein coding genes in the genome

\section{Genome sequencing and assembly}

Genome sequencing was performed using a fragment library with the Ion Torrent ${ }^{\mathrm{TM}}$ Personal Genome Machine System, with 200 bp sequencing kit. The sequencing produced a total of 578,082,183 bp, distributed among $2,973,022$ reads, with an average genome coverage depth of 246-fold and a Phred quality greater than or equal to 20 in $91.25 \%$ of bases. De novo assembly was performed using Mira v3.9.18 [29]. The assembly resulted in 104 contigs, accounting for $2,032,890 \mathrm{bp}$ and an N50 of 104.996 bp.

Twenty of the contigs obtained were randomly used as query on BlastN+ [30], over NR database to identify the most similar $S$. agalactiae complete genome deposited in GenBank. After that, the contigs were ordered and oriented using the software CONTIGuator v2 [31] with S. agalactiae GD201008-001 [32] as a reference genome, generating a pseudo chromosome with 31 scaffolds. The remaining gaps were closed removing overlaps of neighboring contigs and via consensus sequences obtained by 
mapping the raw data against the reference genome using CLC Genomics Workbench 7.0 (Qiagen, USA) [33] and BlastN. Furthermore, only the consensus data was used to close gaps in the rRNA regions.

\section{Genome annotation}

Structural gene prediction was performed using the FGENESB [34]. To choose a reference, twenty random parts of our genome were used as query on BlastN over the available four $S$. agalactiae genomes on FGENESB. Therefore, using S. agalactiae 09mas018883 [35] as reference, the prediction resulted in 1,616 genes. The genome annotation was performed manually with Artemis [36], UniProt databases [37] and Interproscan 5 [38]. During manual annotation, 299 additional genes were added. For the prediction of rRNA and tRNA the software RNAmmer v1.2 [39] and tRNAscan-SE [40] were used, respectively.

\section{Genome properties}

The genome has one circular chromosome with $1,999,151 \mathrm{pb}, 35.48 \% \mathrm{G}+\mathrm{C}$ content, a total of 1,998 CDS, including 1,915 protein-coding genes, 18 rRNAs, 63 tRNAs and 2 pseudogenes. A circular map of the genome was generated using the CGView Comparison Tool [41], shown in Fig. 3. Genome statistics are summarized in Tables 3 and 4. Functional analysis using the COG base showed that approximately $27 \%$ of the genes do not have any described function, which consists in the sum of genes with unknown functions (7.69\%) and genes that were not found in the database (19.97\%).

\section{Insight from the genome sequence}

To predict pathogenic islands, GIPSy software [42] was used. GBS85147 strain was compared against 16 complete strains of the same species found at GenBank. BRIG software [43], was used to view the circular structure of pathogenic Islands and the genome strains. Figure 4a represents the seven predicted pathogenicity islands; especially pathogenicity island 4 that consists of six genes, representing four conserved hypothetical proteins whereas two of them are not conserved in all strains. The first one is "Streptokinase", an enzyme usually secreted by Streptococcus species and has a high therapeutic potential to combat thrombolysis, also currently used to combat heart attack and pulmonary embolism [44]. The second "Glycine betaine/proline transport system", makes part of the glycine betaine transport complex [45]. Glycine is involved in the formation of the peptidoglycan cell wall of Gram-positive bacteria and also helps in securing external cell structures [46], indicating that the bacteria have evolved abilities to survive the stress within the host cells, becoming more resistant to the intracellular environment. Figure $4 \mathrm{~b}$

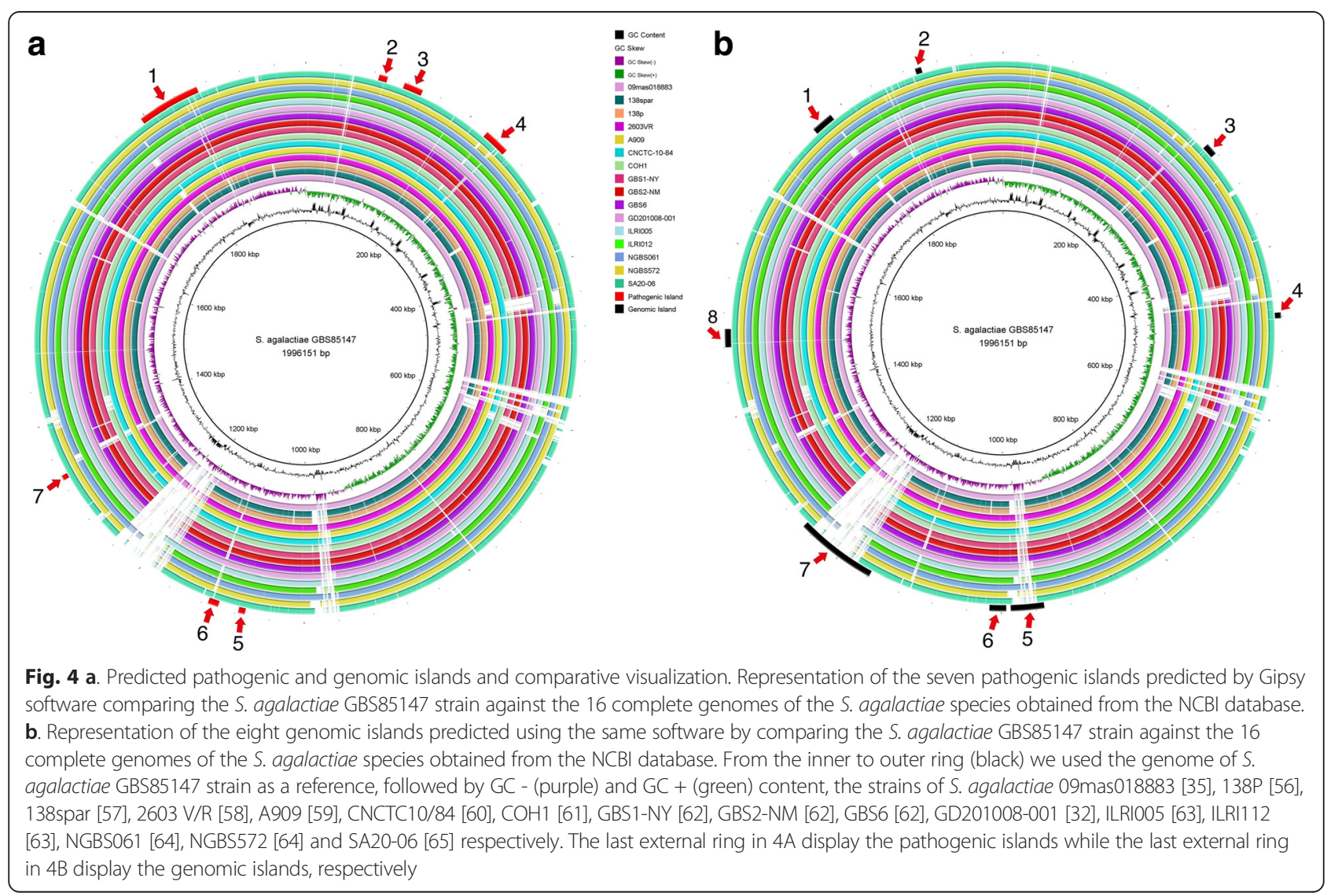


(Additional file 1) shows eight genomic islands of unknown classification. This result indicates that Gipsy recognized the region as a probable genomic island, but could not identify it. An in-depth analysis of the genes present in this island revealed that much of the genes products hypothetical proteins, highlighting an importance of conducting further studies for genes present in this region in order to better characterize their functions.

\section{Conclusion}

The genome sequence of $S$. agalactiae GBS85147, obtained using the Ion Torrent PGM platform with approximately 246-fold coverage, was completely finished, manually annotated, its putative pseudogenes manually curated and the resulting genome file deposited in NCBI. After manual annotation of CDSs, the function of 1,713 (85.73 \%) genes was identified and, after frameshift manual curation, only two pseudogenes remained. The final size of the genome is $\sim 2 \mathrm{Mb}$ with $\mathrm{G}+\mathrm{C}$ content of $35.48 \%$, consistent with the genomes of other strains of the $S$. agalactiae species.

The complete genome of GBS85147, the first isolate of oropharynx of an adult patient in Brazil, can help in further understanding the dissemination of this disease, and improve the identification of genes that allow the $S$. agalactiae serotype Ia to trigger the respiratory oxidative burst during adherence to the surface of activated macrophages. Furthermore, our data may become valuable to future comparative studies with other S. agalactiae strains of different serotypes in order to explore their virulence determinants, evolutionary relationships and the genetic basis of host tropism in S. agalactiae.

\section{Additional file}

\section{Additional file 1: Strain ID Summary. (DOC $26 \mathrm{~kb}$ )}

\section{Acknowledgements}

The authors thank CNPq (Conselho Nacional de Desenvolvimento Científico e Tecnológico), CAPES (Coordenação de Aperfeiçoamento de Pessoal de Nível Superior) and FAPEMIG (Fundação de Amparo a Pesquisa do Estado de Minas Gerais) for the financial support provided to the authors. The authors also thank the National Reference Laboratory for Aquatic Animal Diseases (AQUACEN), Ministry of Fisheries and Aquaculture for supporting the development of this work and Universidade Federal de Minas Gerais for funding the study.

\section{Authors' contributions}

ELA wrote the manuscript and performed the genome annotation; DCBM, FLP, MVCV, LJB, LCO performed the manual annotation and frameshift analyses; FLP gave insights about the manuscript. CAGL, AFC, FAD performed library preparation and sequencing; FSR, FAD prepared DNA samples; GSS, ALMG isolated and identified samples; ACP, ALMG, PEN, VA read, gave insights about the manuscript and coordinated the study; VA, HCPF, SCS, SSH contributed reagents and support sequencing. All authors read and approved the final manuscript.

\section{Competing interests}

The authors declare that they have no competing interests.

\section{Author details}

'Laboratory of Cellular and Molecular Genetics (LGCM), Federal University of Minas Gerais, Belo Horizonte, Brazil. ${ }^{2}$ National Reference Laboratory for Aquatic Animal Diseases (AQUACEN), Ministry of Fisheries and Aquaculture, Federal University of Minas Gerais, Belo Horizonte, Brazil. ${ }^{3}$ Laboratory of Molecular Biology and Physiology of Streptococci, State University of Rio de Janeiro, Rio de Janeiro, Brazil. ${ }^{4}$ Faculty of Medical Sciences - State University of Rio de Janeiro, Rio de Janeiro, Brazil. ${ }^{5}$ Institute of Biological and Natural Sciences (ICBN)- Federal University of Triangulo Mineiro, Uberaba, Minas Gerais, Brazil.

Received: 5 August 2015 Accepted: 23 May 2016

Published online: 03 June 2016

\section{References}

1. Farley MM. Group B, streptococcal disease in nonpregnant adults. Clin Infect Dis Off Publ Infect Dis Soc Am. 2001;33:556-61.

2. Park SE, Jiang $\mathrm{S}$, Wessels MR. CsrRS and environmental $\mathrm{pH}$ regulate group $\mathrm{B}$ streptococcus adherence to human epithelial cells and extracellular matrix. Infect Immun. 2012:80:3975-84.

3. Rajagopal L. Understanding the regulation of Group B streptococcal virulence factors. Future Microbiol. 2009;4:201-21.

4. Chen M, Wang R, Li L-P, et al. Screening vaccine candidate strains against Streptococcus agalactiae of tilapia based on PFGE genotype. Vaccine. 2012;30:6088-92.

5. Delannoy CM, Crumlish M, Fontaine MC, et al. Human Streptococcus agalactiae strains in aquatic mammals and fish. BMC Microbiol. 2013;13:41.

6. Foxman B, Gillespie BW, Manning SD, Marrs CF. Risk factors for group B streptococcal colonization: potential for different transmission systems by capsular type. Ann Epidemiol. 2007;17:854-62

7. Richards V, Lang P, Pavinski Paulina E, et al. Comparative genomics and the role of lateral gene transfer in the evolution of bovine adapted Streptococcus agalactiae. Infect Genet Evol. 2011;2011:1263-75.

8. Mian GF, Godoy DT, Leal CAG, Yuhara TY, Costa GM, Figueiredo HCP. Aspects of the natural history and virulence of $S$. agalactiae infection in Nile tilapia. Vet Microbiol. 2009;136:180-3.

9. Pereira UP, Mian GF, Oliveira ICM, Benchetrit LC, Costa GM, Figueiredo HCP. Genotyping of Streptococcus agalactiae strains isolated from fish, human and cattle and their virulence potential in Nile tilapia. Vet Microbiol. 2010;140:186-92.

10. Phares CR, Lynfield R, Farley MM, Mohle-Boetani J, Harrison LH, Petit S, Craig AS, Schaffner W, Zansky SM, Gershman K, Stefonek KR. Epidemiology of invasive group B streptococcal disease in the united states, 1999-2005. Yearb Med. 2008:2008:100-1.

11. Skoff $T H$, Farley MM, Petit $S$, et al. Increasing burden of invasive group $B$ streptococcal disease in nonpregnant adults, 1990-2007. Clin Infect Dis. 2009;49:85-92.

12. Martins ER, Melo-Cristino J, Ramirez M. Dominance of Serotype la among Group B Streptococci Causing Invasive Infections in Nonpregnant Adults in Portugal. J Clin Microbiol. 2012;50:1219-27.

13. Teixeira CF, Azevedo NL, Carvalho TM, Fuentes J, Nagao PE. Cytochemical study of Streptococcus agalactiae and macrophage interaction. Microsc Res Tech. 2001:54:254-9.

14. Monteiro GCTS, Hirata Jr R, Andrade AFB, Mattos-Guaraldi AL, Nagao PE. Surface carbohydrates as recognition determinants in non-opsonic interactions and intracellular viability of group B Streptococcus strains in murine macrophages. Int J Mol Med. 2004;13:175-80.

15. Lione VO, Santos GS, Hirata Junior R, Mattos-Guaraldi AL, Nagao PE. Involvement of intercellular adhesion molecule-1 and beta1 integrin in the internalization process to human endothelial cells of group B Streptococcus clinical isolates. Int J Mol Med. 2005;15:153-7.

16. Soares GCT, Alviano DS, da Silva SG, Alviano CS, Mattos-Guaraldi AL, Nagao PE. Prevalence of group B streptococcus serotypes III and $V$ in pregnant women of Rio de Janeiro Brazil. Braz J Microbiol. 2013:44:869-72.

17. Mattos-Guaraldi AL, Cappelli EA, Previato JO, Formiga LC, Andrade AF. Characterization of surface saccharides in two Corynebacterium diphtheriae strains. FEMS Microbiol Lett. 1999;170:159-66.

18. Schuchat A. Epidemiology of group B streptococcal disease in the United States: shifting paradigms. Clin Microbiol Rev. 1998;11:497-513. 
19. Glaser P, Rusniok C, Buchrieser C, et al. Genome sequence of Streptococcus agalactiae, a pathogen causing invasive neonatal disease. Mol Microbiol. 2002:45:1499-513.

20. Caliot É, Dramsi S, Chapot-Chartier M-P, et al. Role of the group B antigen of streptococcus agalactiae: a peptidoglycan-anchored polysaccharide involved in cell wall biogenesis. PLoS Pathog. 2012;8:1-12.

21. Quentin R, Huet H, Wang F, Geslin P, Goudeau A. Characterization of streptococcus agalactiae strains by multilocus enzyme genotype and serotype: identification of multiple virulent clone families that cause invasive neonatal disease. J Clin Microbiol. 1995;33:2576-81.

22. Ramaswamy SV, Ferrieri P, Madoff LC, et al. Identification of novel cps locus polymorphisms in nontypable group B Streptococcus. J Med Microbiol. 2006:55:775-83.

23. Centers for Disease Control and Prevention. Prevention of perinatal group B streptococcal disease. Mmwr. 2010;59:1-32.

24. Slotved H-C, Kong F, Lambertsen L, Sauer S, Gilbert GL. Serotype IX, a proposed New Streptococcus agalactiae serotype. J Clin Microbiol. 2007;45:2929-36

25. Kong F, Lambertsen LM, Slotved H-C, Ko D, Wang H, Gilbert GL. Use of phenotypic and molecular serotype identification methods to characterize previously nonserotypeable group B streptococci. J Clin Microbiol. 2008:46:2745-50.

26. Luce E. Koneman's color atlas and textbook of diagnostic microbiology, 6th edition. Plast Reconstr Surg. 2010;125:414-5.

27. Field D, Garrity G, Gray T, et al. The minimum information about a genome sequence (MIGS) specification. Nat Biotechnol. 2008;26:541-7.

28. Sambrook J, Russell DW. Molecular Cloning - Sambrook \& Russel - Vol. 1, 2, 3. Cold Spring Harbor, NY, USA: Cold Spring Harbor Laboratory Press; 2001.

29. Chevreux B, Wetter T, Suhai S. Genome sequence assembly using trace signals and additional sequence information. Comput Sci Biol Proc Ger Conf Bioinforma. 1999;99:45-56.

30. Altschul SF, Gish W, Miller W, Myers EW, Lipman DJ. Basic local alignment search tool. J Mol Biol. 1990;215:403-10.

31. Galardini M, Biondi EG, Bazzicalupo M, Mengoni A. CONTIGuator: a bacterial genomes finishing tool for structural insights on draft genomes. Source Code Biol Med. 2011;6:11.

32. Liu G, Zhang W, Lu C. Complete Genome Sequence of Streptococcus agalactiae GD201008-001, Isolated in China from Tilapia with Meningoencephalitis. J Bacteriol. 2012;194:6653.

33. Sequencing H. CLC Genomics Workbench. Workbench. 2011:1-4

34. Culligan EP, Marchesi JR, Hill C, Sleator RD. Combined metagenomic and phenomic approaches identify a novel salt tolerance gene from the human gut microbiome. Front Microbiol. 2014;5:189.

35. Zubair S, De Villiers EP, Fuxelius HH, et al. Genome Sequence of Streptococcus agalactiae Strain 09mas018883, Isolated from a Swedish Cow. Genome Announc. 2013;1:1-2.

36. Rutherford K, Parkhill J, Crook J, et al. Artemis: sequence visualization and annotation. Bioinforma Oxf Engl. 2000;16:944-5.

37. Consortium TU, The UniProt Consortium, Consortium TU. Update on activities at the Universal Protein Resource (UniProt) in 2013. Nucleic Acids Res. 2013;41:D43-7.

38. Jones P, Binns D, Chang H-Y, et al. InterProScan 5: genome-scale protein function classification. Bioinformatics. 2014:30:1236-40.

39. Lagesen $\mathrm{K}$, Hallin $\mathrm{P}$, Rodland EA, Staerfeldt H-H, Rognes T, Ussery DW. RNAmmer: consistent and rapid annotation of ribosomal RNA genes. Nucleic Acids Res. 2007;35:3100-8.

40. Lowe TM, Eddy SR. tRNAscan-SE: a program for improved detection of transfer RNA genes in genomic sequence. Nucleic Acids Res. 1997;25:955-64.

41. Grant JR, Stothard P. The CGView server: a comparative genomics tool for circular genomes. Nucleic Acids Res. 2008;36:181-4.

42. Soares SC, Geyik H, Ramos RTJ, et al. GIPSy: genomic island prediction software. J Biotechnol. 2015.

43. Alikhan N-F, Petty NK, Ben Zakour NL, Beatson SA. BLAST Ring Image Generator (BRIG): simple prokaryote genome comparisons. BMC Genomics. 2011;12:402.

44. Sikri N, Bardia A. A history of streptokinase use in acute myocardial infarction. Tex Heart Inst J Tex Heart Inst St Lukes Episcop Hosp Tex Child Hosp. 2007;34:318-27.

45. KEGG. Glycine betaine/proline transport system. 2015:1. Available at: http://www.kegg.jp/module/M00208. Accessed 27 Oct 2015.
46. Madigan MT, Martinko JM, Dunlap PV, Clark DP. Microbiologia de Brock. 12a Ed. Porto Alegre: Artmed; 2010. p. 1128.

47. Woese CR, Kandler O, Wheelis ML. Towards a natural system of organisms: proposal for the domains archaea, bacteria, and eucarya. Proc Natl Acad Sci U S A. 1990;87:4576-9.

48. Gibbons NE, Murray RGE. Proposals concerning the higher taxa of bacteria. Int J Syst Evol Microbiol. 1978;28:1-6.

49. Ludwig W, Schleifer KH, Whitman WB. Class I. Bacilli class nov. Bergey's Manual of Systematic Bacteriology 2009, 3: 19-20. List of new names and new combinations previously effectively, but not validly, published. List no. 132. Int J Syst Evol Microbiol. 2010;60:469-72.

50. Ludwig W, Schleifer KH, Whitman WB. Order II. Lactobacillales ord. nov. Bergey's Manual of Systematic Bacteriology 2009, 3: 464. List of new names and new combinations previously effectively, but not validly, published. List no. 132. Int J Syst Evol Microbiol. 2010;60:469-72

51. Deibel RH, Seeley HW. Family II. Streptococcaceae. Bergey's Manual of Determinative Bacteriology 1974, 490-515. Skerman VBD, McGowan V, Sneath PHA: Approved Lists of Bacterial Names. Int J Syst Bact. 1980;30:225-420.

52. Rosenbach FJ. Microorganismen bei den Wund-Infections-Krankheiten des Menschen. Microorganismen bei den Wund-Infections-Krankheiten des Menschen. 1884, 1-122.Skerman VBD, McGowan V, Sneath PHA: Approved Lists of Bacterial Names. Int J Syst Bact. 1980;30:225-420.

53. Lehmann KB, Neumann R. Atlas und Grundriss der Bakteriologie und Lehrbuch der speziellen bakteriologischen Diagnostik. Atlas und Grundriss der Bakteriologie und Lehrbuch der speziellen bakteriologischen Diagnostik 1896, 1-448. Skerman VBD, McGowan V, Sneath PHA: Approved Lists of Bacterial Names. Int J Syst Bact. 1980;30:225-420.

54. Bergey DH. Bergey's Manual of Systematic Bacteriology. 2nd ed. - Vol 4. Bacteroidetes; 2010:949.

55. Rogers MF, Ben-Hur A. The use of gene ontology evidence codes in preventing classifier assessment bias. Bioinformatics. 2009;25:1173-7.

56. Pridgeon JW, Zhang D. Complete genome sequence of a virulent streptococcus agalactiae strain, 138P, isolated from diseased Nile Tilapia. Genome Announc. 2014:2:2013-4.

57. Pridgeon JW, Zhang D, Zhang L. Complete genome of the attenuated sparfloxacin-resistant Streptococcus agalactiae strain 138spar. Genome Announc. 2014;2:78-9.

58. Masignani V, Cieslewicz MJ, Eisen JA, et al. Complete genome sequence and comparative genomic analysis of an emerging human pathogen, serotype V Streptococcus agalactiae. Proc Natl Acad Sci U S A. 2002;99:12391-6.

59. Tettelin H, Masignani V, Cieslewicz MJ, et al. Genome analysis of multiple pathogenic isolates of Streptococcus agalactiae: implications for the microbial "pan-genome". Proc Natl Acad Sci U S A. 2005;102:13950-5.

60. Hooven TA, Randis TM, Daugherty SC, et al. Complete Genome Sequence of Streptococcus agalactiae CNCTC 10/84, a Hypervirulent Sequence Type 26 Strain. Genome Announc. 2014;2:361-2

61. Da Cunha V, Davies MR, Douarre P, Rosinski- I. Streptococcus agalactiae clones infecting humans were selected and fixed through the extensive use of tetracycline. Eur PMC Funders Group. 2015;337549:1-23.

62. Srinivasan V, Metcalf BJ, Knipe KM, et al. van G element insertions within a conserved chromosomal site conferring vancomycin resistance to Streptococcus agalactiae and Streptococcus anginosus. mBio. 2014:5:e01386-14

63. Zubair S, De Villiers EP, Younan M, et al. Genome sequences of Two pathogenic Streptococcus agalactiae isolates from the One-humped came camelus dromedarius. Genome Announc. 2013;1:13-4.

64. Tatusova T, Ciufo S, Fedorov B, O’Neill K, Tolstoy I. RefSeq microbial genomes database: new representation and annotation strategy. Nucleic Acids Res. 2014:42:D553-9.

65. Pereira UDP, Rodrigues Dos Santos A, Hassan SS, et al. Complete genome sequence of Streptococcus agalactiae strain SA20-06, a fish pathogen associated to meningoencephalitis outbreaks. Stand Genomic Sci. 2013:8:188-97. 